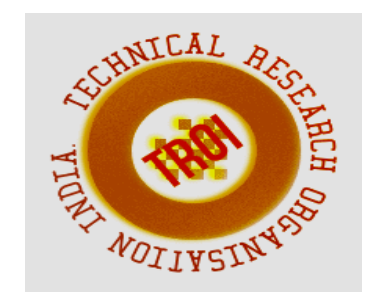

\title{
STABILIZATION OF BLACK COTTON SOIL USING RICE HUSK ASH AND CRUMB RUBBER
}

\author{
${ }^{1}$ Silviya L, ${ }^{2}$ Syed Ariff, ${ }^{3}$ Priyanka P, ${ }^{4}$ Murali B, ${ }^{5}$ Suchandra Pradhan, ${ }^{6}$ Krishne Gowda S \\ ${ }^{1}$ Assistant Professor, ${ }^{2}$ Professor \& Principal, ${ }^{3,4,5,6}$ Students \\ Department of Civil Engineering, Dr. T. Thimmaiah Institute of Technology, Oorgaum, K.G.F, \\ Karnataka, India \\ Email id: silviya@drttit.edu.in
}

\section{ABSTRACT}

Black Cotton Soil (BCS) is a major soil deposit in India. There is a presence of significant amount of mineral montmorillonite in BCS which is the reason behind the alternate swell-shrink property which occurs due to the changes in moisture content and has proven to be troublesome in carrying out civil engineering activities. To encounter this problem stabilization is in practice. The utilization of waste materials such as Rice Husk Ash (RHA), Crumb Rubber (CR) as soil stabilizers is being carried out in our research paper. As the disposal of scrap tyres and agricultural wastes has a potential negative impact on the environment causing pollution and finally affects the ecosystem, thus it is mandatory to make use of these wastes in an environmentally friendly way. The main objective of the paper is to study the geotechnical properties i.e. the Consistency limits, Unconfined Compression Strength, Compaction parameters and CBR characteristics. RHA and CR are blended along with BCS in different proportions and the geotechnical properties of stabilized soil samples are examined. Ultimately the results being computed are studied and the suitable soil stabilizer which proves to be effective enough to withstand the variations and resist the deformations is being suggested.

Key Words: Black Cotton Soil (BCS), Rice Husk Ash (RHA), Crumb Rubber (CR), Liquid Limit(LL), Plastic Limit(PL),
Unconfined Compression Strength(UCS), California Bearing Ratio(CBR)

\section{INTRODUCTION}

Black Cotton Soil is considered to be weak soil and has low stability against heavy loading. In order to withstand the heavy loading, the soil needs to be stabilized. By stabilizing the soil its engineering properties will be improved. BCS absorbs moisture from the surface during monsoon and exudes moisture by means of evaporation during summer season. Due to this property of soil it is recognized as an expansive soil. It is greyish to blackish in colour and contains montmorillonite clay mineral. Stabilization is a process of changing chemical properties of soil by adding stabilizers to increase the strength and stiffness of expansive (weak) soils. The stabilizers utilized in this research paper are Rice Husk Ash and Crumb Rubber.

\section{MATERIALS}

Black Cotton Soil taken for the investigation is procured from Mavinalli, Indi Taluk, Bijapur District. BCS is derived from basaltic bedrock and is alkaline in nature with low potassium and nitrogen content. Table 1 describes the properties of BCS alone.

Table: 1 Properties of Black Cotton Soil

\begin{tabular}{|c|c|}
\hline Property & Value \\
\hline Specific Gravity & 2.78 \\
\hline Liquid Limit (\%) & 69 \\
\hline Plastic Limit (\%) & 37.5 \\
\hline Plasticity Index (\%) & 31.5 \\
\hline
\end{tabular}




\begin{tabular}{|c|c|}
\hline Flow Index (\%) & 65 \\
\hline OMC (\%) & 24 \\
\hline MDD (g/cc) & 1.7 \\
\hline UCS $\left(\mathrm{KN} / \mathrm{m}^{2}\right)$ & 44.14 \\
\hline CBR $(\%)$ & 2.2 \\
\hline
\end{tabular}

Rice Husk Ash is being procured from R.K.Rice Mill, Deshihalli, Bangarpet Taluk, Kolar District. Rice Husk is an agricultural waste obtained from milling of rice. Rice Husk due to its abrasive character, high ash and lignin content it is unsuitable as a raw material for paper industry as well as animal feed. On burning Rice Husk the ash obtained contains high amount of silica in it which is most suited for a good soil stabilizer. Table 2 describes the constituents of RHA.

Table: 2 Properties of Rice Husk Ash

\begin{tabular}{|c|c|}
\hline Constituents & Composition (\%) \\
\hline $\mathrm{SiO}_{2}$ & 82.6 \\
\hline $\mathrm{Al}_{2} \mathrm{O}_{3}$ & 0.4 \\
\hline $\mathrm{Fe}_{2} \mathrm{O}_{3}$ & 0.5 \\
\hline $\mathrm{CaO}$ & 0.9 \\
\hline $\mathrm{K}_{2} \mathrm{O}$ & 1.8 \\
\hline $\mathrm{MnO}$ & 0.3 \\
\hline $\mathrm{SO}_{3}$ & $<0.1$ \\
\hline $\mathrm{MgO}_{2}$ & 0.7 \\
\hline $\mathrm{P}_{2} \mathrm{O}_{5}$ & 0.9 \\
\hline Loss On Ignition((LOI) & 11.9 \\
\hline
\end{tabular}

Crumb Rubber used in this investigation is obtained from Kolar-Vemgal Rubber Retreading Center. Rubber doesn't decompose as a result an economically feasible and environmentally sound disposal method must be followed. Use of Crumb Rubber as a stabilizer serves a new resource in construction industry. Table 3 describes the properties of Crumb Rubber.

Table: 3 Properties of Crumb Rubber

\begin{tabular}{|c|c|}
\hline Constituents & Composition (\%) \\
\hline Acetone extract & 10.0 \\
\hline Rubber hydrocarbon & 25.0 \\
\hline Carbon black content & 30 \\
\hline Natural Rubber content & 31.0 \\
\hline Ash content & 4.0 \\
\hline
\end{tabular}

\section{METHODOLOGY}

Black Cotton Soil and the soil stabilizers Rice Husk Ash and Crumb Rubber procured are pulverized. Firstly, tests are conducted on Black Cotton Soil alone in order to determine its properties. Further, Black Cotton Soil is treated with Rice Husk Ash and Crumb Rubber in varying proportions and the test conducted describe its geotechnical property.

Samples tested:

1. Samples treated with Rice Husk Ash on increments of $5,10,15,20,20,25$, and $30 \%$.

2. Samples treated with Crumb Rubber on increments of 5, 10, 15, 20, 25, and 30\%.

3. Samples treated with combination of Rice Husk Ash and Crumb Rubber in equal parts of the proportion taken in the increments of $5,10,15,20,25$, and $30 \%$.

\section{EXPERIMENTAL INVESTIGATIONS \& RESULT ANALYSIS}

In order to study the effect of Rice Husk Ash and Crumb Rubber, they are mixed in varying proportions and are blended with Black Cotton Soil. Further the laboratory tests are conducted and results computed are analyzed and represented in the below tables and graphs.

\subsection{Atterberg Limits}

Atterberg limits include Liquid limit and Plastic limit. Liquid Limit test is conducted by the Casagrande apparatus. Table 4 describes the effect of varying proportions of stabilizers RHA and CR on Liquid Limit of Black Cotton Soil and is graphically represented in Fig.1.Table 5 describes the effect of varying proportions of stabilizers RHA and CR on Plastic Limit of BCS and is graphically represented in Fig. 2.

Table: 4 Effect of stabilizers RHA \& CR on LL of BCS

\begin{tabular}{|c|c|c|c|}
\hline \multicolumn{4}{|c|}{ LIQUID LIMIT (\%) } \\
\hline $\begin{array}{c}\text { \% of Soil } \\
\text { Stabilizer }\end{array}$ & $\begin{array}{c}\text { BCS+ } \\
\text { RHA }\end{array}$ & $\begin{array}{c}\text { BCS+ } \\
\text { CR }\end{array}$ & BCS+RHA+CR \\
\hline 0 & 69 & 69 & 69 \\
\hline 5 & 41 & 61 & 44 \\
\hline 10 & 34 & 52 & 43 \\
\hline 15 & 33 & 35 & 39 \\
\hline 20 & 45 & 40 & 34 \\
\hline 25 & 60.4 & 45 & 52 \\
\hline 30 & 62 & 62.5 & 60.4 \\
\hline \multicolumn{3}{|c}{} \\
\hline
\end{tabular}




\section{LIQUID LIMIT(LL)}

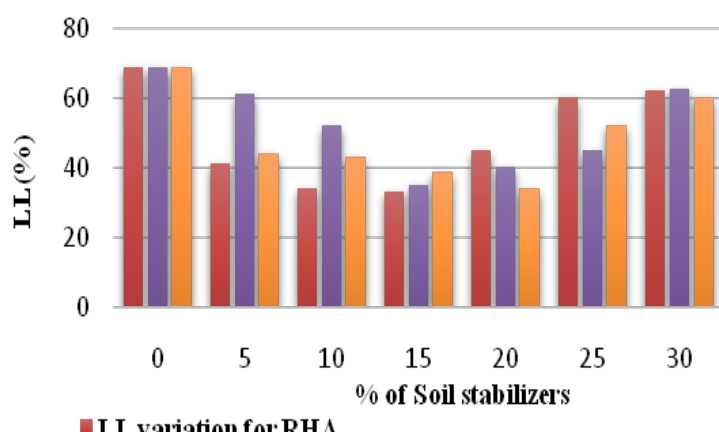

- $L L$ variation for $C R$

I.I. variation for the mix combination of RHA and CR

Fig. 1 LL variation for the various mixes of RHA and $C R$

Table: 5 Effect of stabilizers RHA \& CR on PL of BCS

\begin{tabular}{|c|c|c|c|}
\hline \multicolumn{4}{|c|}{ PLASTIC LIMIT (\%) } \\
\hline $\begin{array}{c}\text { \% of Soil } \\
\text { Stabilizer }\end{array}$ & $\begin{array}{c}\text { BCS+ } \\
\text { RHA }\end{array}$ & $\begin{array}{c}\text { BCS+ } \\
\text { CR }\end{array}$ & BCS+RHA+CR \\
\hline 0 & 37.5 & 37.5 & 37.5 \\
\hline 5 & 33 & 42 & 32.65 \\
\hline 10 & 25 & 62.5 & 22.2 \\
\hline 15 & 23.3 & 32.65 & 16.7 \\
\hline 20 & 32.65 & 75 & 36.6 \\
\hline 25 & 42 & 76.5 & 43 \\
\hline 30 & 54.22 & 80.2 & 52.2 \\
\hline
\end{tabular}

PLASTIC LIMIT(PL)

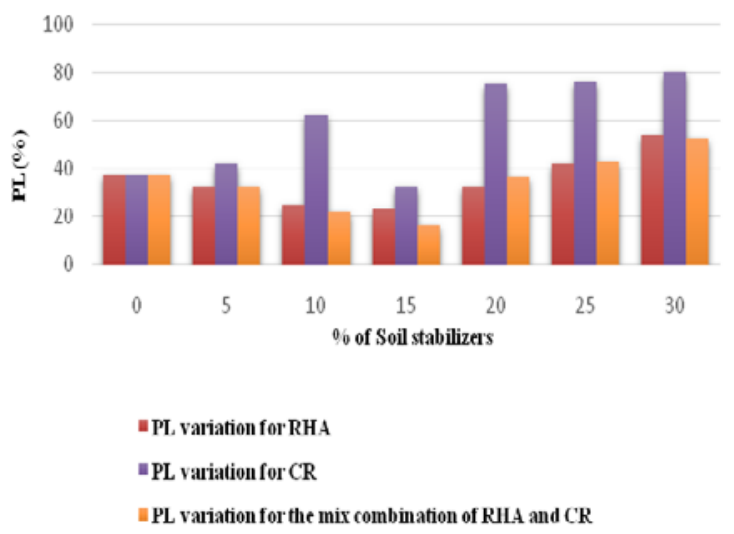

Fig. 2 PL variation for the various mixes of RHA and $C R$

The determination of Plasticity Index and Flow Index is being done for the various proportions of Rice Husk A and Crumb Rubber with Black Cotton Soil. The following Table 3 and 4 represents the values of Plasticity Index and
Flow Index respectively. The corresponding graphs are being represented as below Fig. 3 and Fig.4.

Table: 6 Effect of stabilizers RHA \& CR on PI of BCS

\begin{tabular}{|c|c|c|c|}
\hline \multicolumn{4}{|c|}{ PLASTICITY INDEX (\%) } \\
\hline $\begin{array}{c}\text { \% of Soil } \\
\text { Stabilizer }\end{array}$ & $\begin{array}{c}\text { BCS+ } \\
\text { RHA }\end{array}$ & $\begin{array}{c}\text { BCS+ } \\
\text { CR }\end{array}$ & BCS+RHA+CR \\
\hline 0 & 31.5 & 31.5 & 31.5 \\
\hline 5 & 18.4 & 19.34 & 22.3 \\
\hline 10 & 9.1 & 10.5 & 20.8 \\
\hline 15 & 9.7 & 2.35 & 11.35 \\
\hline 20 & 7.78 & 35 & 2.6 \\
\hline 25 & 12.35 & 31.5 & 8.2 \\
\hline 30 & 23.85 & 47.7 & 9 \\
\hline \multicolumn{4}{|c}{} \\
\hline
\end{tabular}

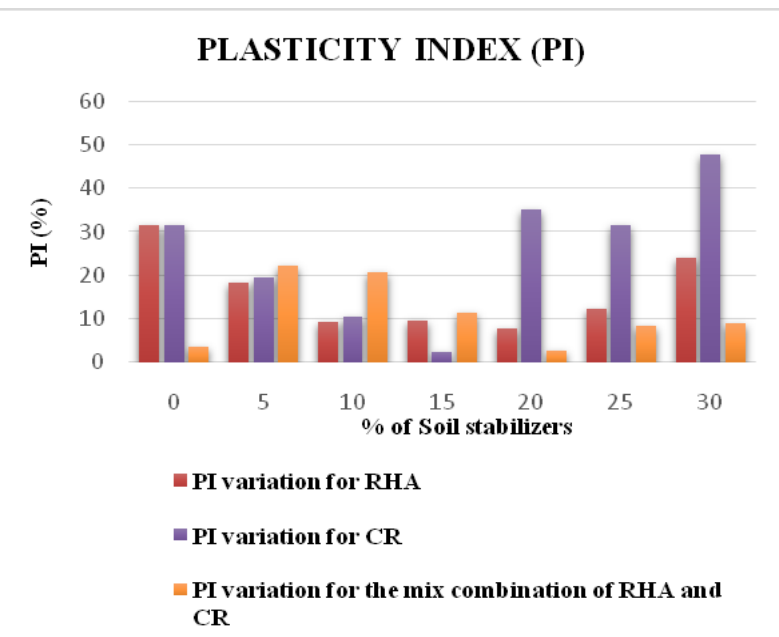

Fig. 3 PI variation for the various mixes of RHA and $C R$

Table: 7 Effect of stabilizers RHA \& CR on FI of BCS

\begin{tabular}{|c|c|c|c|}
\hline \multicolumn{4}{|c|}{ FLOW INDEX (\%) } \\
\hline $\begin{array}{c}\text { \% of Soil } \\
\text { Stabilizer }\end{array}$ & $\begin{array}{c}\text { BCS+ } \\
\text { RHA }\end{array}$ & $\begin{array}{c}\text { BCS+ } \\
\text { CR }\end{array}$ & BCS+RHA+CR \\
\hline 0 & 65 & 65 & 65 \\
\hline 5 & 56 & 56 & 60 \\
\hline 10 & 46 & 35 & 43 \\
\hline 15 & 33 & 30 & 22 \\
\hline 20 & 50 & 23 & 56 \\
\hline 25 & 60 & 45 & 64 \\
\hline 30 & 65 & 52 & 70 \\
\hline
\end{tabular}




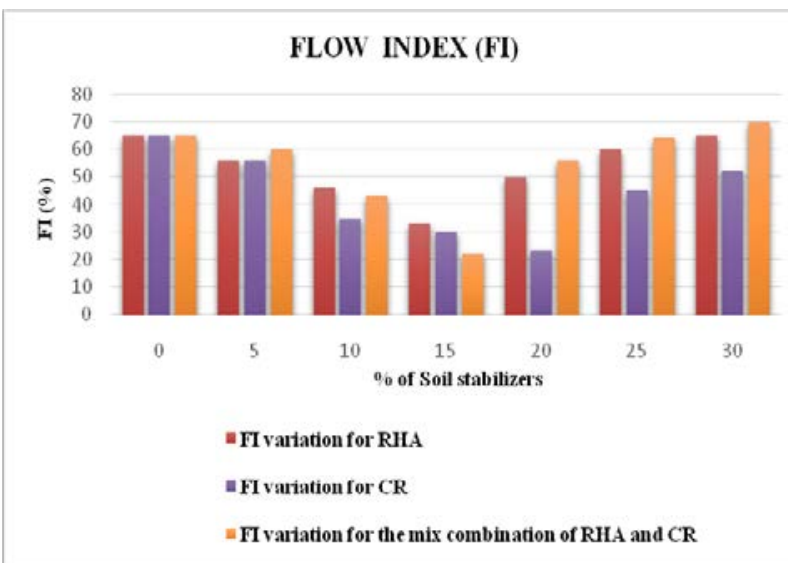

Fig. 4 FL variation for the various mixes of RHA and CR

\subsection{Compaction Characteristics}

The Standard Proctor test is conducted on Black Cotton Soil with the varying proportions of RHA and CR and the determination of Maximum Dry Density and Optimum Moisture Content is carried out. The mould is compacted in three layers by 25 blows. By oven drying the samples for 24 hrs the OMC is determined. Table 6 describes the effect of varying proportions of RHA and CR on OMC of BCS and is graphically represented in Fig.3. Table 7 describes the effect of varying proportions of RHA and CR on MDD of BCS and is graphically represented in Fig.4.

Table: 8 Effect of stabilizers RHA \& CR on OMC of BCS

\begin{tabular}{|c|c|c|c|}
\hline \multicolumn{5}{|c|}{ OPTIMUM MOISTURE CONTENT (\%) } \\
\hline $\begin{array}{c}\text { \% of Soil } \\
\text { Stabilizer }\end{array}$ & $\begin{array}{c}\text { BCS+ } \\
\text { RHA }\end{array}$ & $\begin{array}{c}\text { BCS+ } \\
\text { CR }\end{array}$ & BCS+RHA+CR \\
\hline 0 & 24 & 24 & 24 \\
\hline 5 & 22 & 22.2 & 23 \\
\hline 10 & 20 & 14 & 20 \\
\hline 15 & 19.5 & 18 & 18 \\
\hline 20 & 18.18 & 32.5 & 38.1 \\
\hline 25 & 32.5 & 36 & 10.55 \\
\hline 30 & 42 & 40.2 & 36 \\
\hline
\end{tabular}

OPTIMUM MOISTURE CONTENT(OMC)

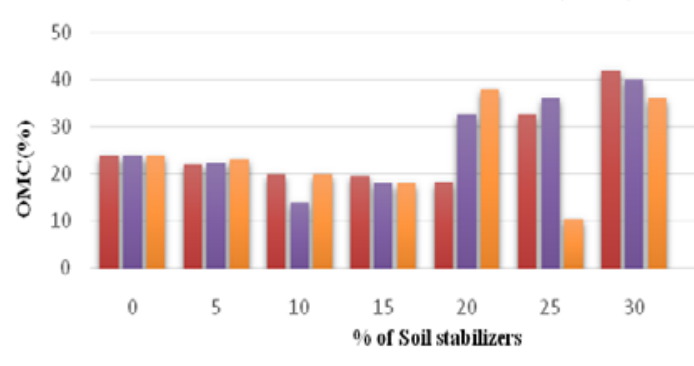

wOMC variation for RHA

= OMC variation for $\mathrm{CR}$

=OMC variation for the mix combination of RHA and CR
Fig. 5 OMC variation for the various mixes of RHA and $C R$

Table: 9 Effect of stabilizers RHA and CR on MDD of BCS

\begin{tabular}{|c|c|c|c|}
\hline \multicolumn{4}{|c|}{ MAXIMUM DRY DENSITY (g/Cc) } \\
\hline $\begin{array}{c}\text { \% of Soil } \\
\text { Stabilizer }\end{array}$ & $\begin{array}{c}\text { BCS+ } \\
\text { RHA }\end{array}$ & $\begin{array}{c}\text { BCS+ } \\
\text { CR }\end{array}$ & BCS+RHA+CR \\
\hline 0 & 1.7 & 1.7 & 1.7 \\
\hline 5 & 1.72 & 1.65 & 1.7 \\
\hline 10 & 1.74 & 1.72 & 1.72 \\
\hline 15 & 1.75 & 1.7 & 1.73 \\
\hline 20 & 1.4 & 1.32 & 1.2 \\
\hline 25 & 1.3 & 1.3 & 1.3 \\
\hline 30 & 1.2 & 1.2 & 1.3 \\
\hline
\end{tabular}

MAXIMUM DRY DENSITY(MDD)

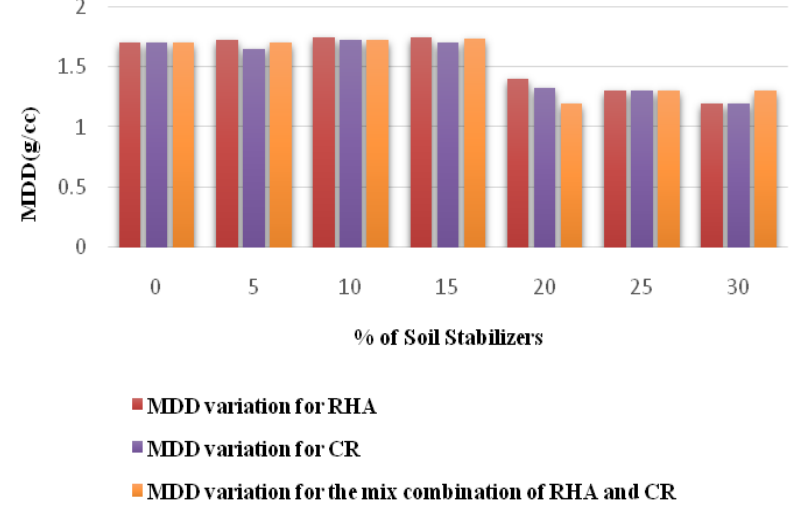

Fig. 6 MDD variation for the various mixes of RHA and $C R$

\subsection{Unconfined Compression Strength}

UCS test is conducted on BCS along with varying proportions of RHA and $\mathrm{CR}$ and the strength parameter is determined. Cylindrical specimens of OMC corresponding to its standard proctor test of $3.72 \mathrm{~cm}$ diameter and $7.65 \mathrm{~cm}$ height are compacted. These prepared samples are tested, and the comparative result analysis is carried out. Table 8 describes the effect of varying proportions of RHA and CR on UCS of BCS and is graphically represented in Fig.5.

Table: 10 Effect of stabilizers RHA and CR on UCS of BCS

\begin{tabular}{|c|c|c|c|}
\hline \multicolumn{4}{|c|}{ UNCONFINED COMPRESSION } \\
STRENGTH $\left(\mathrm{kN} / \mathrm{m}^{2}\right)$ \\
\hline $\begin{array}{c}\text { \% of Soil } \\
\text { Stabilizer }\end{array}$ & $\begin{array}{c}\text { BCS+ } \\
\text { RHA }\end{array}$ & $\begin{array}{c}\text { BCS+ } \\
\text { CR }\end{array}$ & BCS+RHA+CR \\
\hline 0 & 44.14 & 44.14 & 44.14 \\
\hline 5 & 51.012 & 48.06 & 66.4 \\
\hline 10 & 55.19 & 53.6 & 56.89 \\
\hline 15 & 68.67 & 23.74 & 85.34 \\
\hline 20 & 60.22 & 22.44 & 68.67 \\
\hline
\end{tabular}




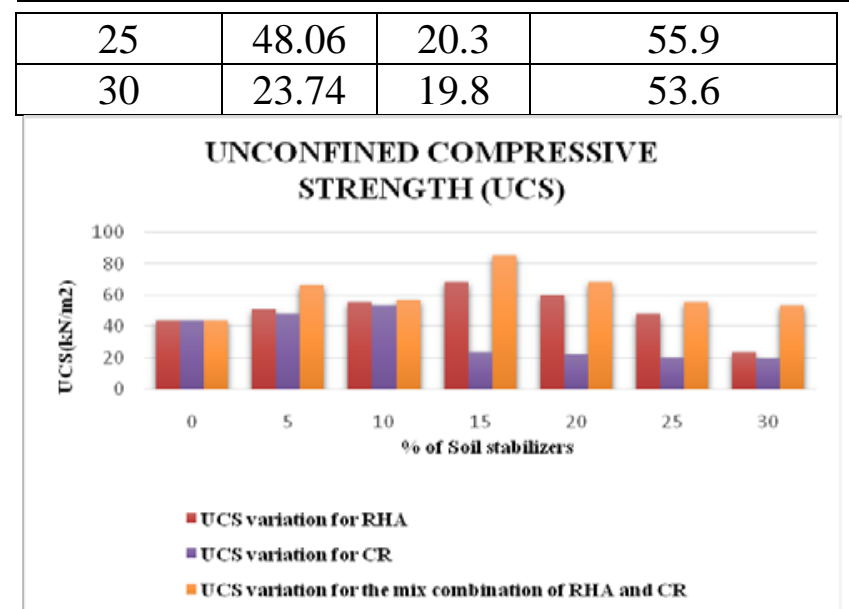

Fig. 7 UCS variation for the various mixes of RHA and $C R$

\subsection{CBR Percent}

CBR penetration test is conducted on BCS along with varying proportions of RHA and CR and the mechanical strength of natural ground is evaluated. At $2.5 \mathrm{~mm}$ penetration of the plunger the CBR percent is computed. Table 9 describes the effect of varying proportions of RHA and CR on UCS and is graphically represented in Fig.6.

Table: 11 Effect of stabilizers RHA and CR on $C B R$ percent of $B C S$

\begin{tabular}{|c|c|c|c|}
\hline \multicolumn{4}{|c|}{ CBR (\%) } \\
\hline $\begin{array}{c}\text { \% of Soil } \\
\text { Stabilizer }\end{array}$ & $\begin{array}{c}\text { BCS+ } \\
\text { RHA }\end{array}$ & $\begin{array}{c}\text { BCS+ } \\
\text { CR }\end{array}$ & BCS+RHA+CR \\
\hline 0 & 2.2 & 2.2 & 2.2 \\
\hline 5 & 2.8 & 2.0 & 2.3 \\
\hline 10 & 2.9 & 3.27 & 2.76 \\
\hline 15 & 2.6 & 2.3 & 2.915 \\
\hline 20 & 1.02 & 1.1 & 2.8 \\
\hline 25 & 1.1 & 1.1 & 2.6 \\
\hline 30 & 0.72 & 1.82 & 2.4 \\
\hline
\end{tabular}

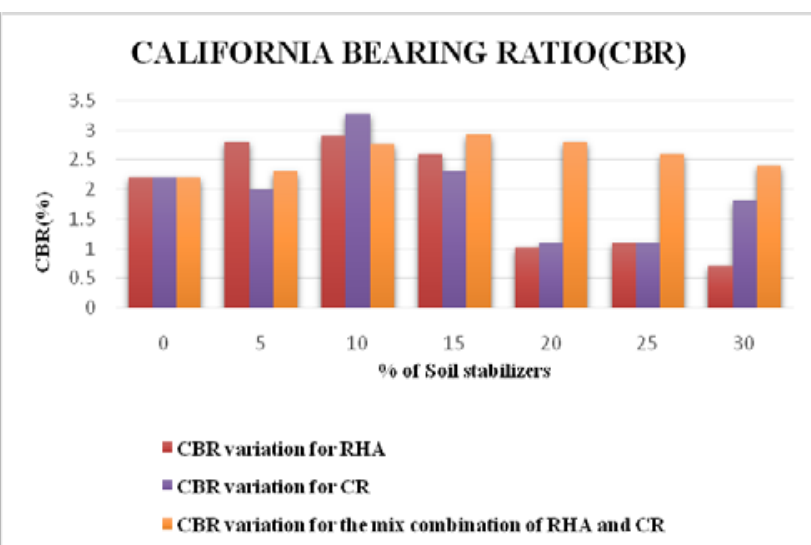

Fig. 8 CBR variation for the various mixes of RHA and CR
5. OBSERVATION \& DISCUSSION 5.1 Effect of RHA on BCS

The optimum proportion of Rice Husk Ash blended with Black Cotton Soil which yields better results when compared to the other proportions of RHA is enumerated below:

1. LL initially for BCS is $69 \%$ and on addition of RHA, LL reduces up to an increment of $15 \%$ and the value was found to be $33 \%$ and on further increment the LL increases.

2. PL initially for BCS is $37.5 \%$ and on addition of RHA PL decreases up to an increment of $15 \%$ and was found to be $23.3 \%$ and on further increment the PL increases.

3. OMC and MDD for BCS alone is $24 \%$ and $1.7 \mathrm{~g} / \mathrm{cc}$ respectively and on addition of RHA the OMC value decreases up to an increment of $20 \%$ RHA and the value is $18.18 \%$, similarly the MDD value increases up to $15 \%$ increment of RHA and the value is $1.75 \mathrm{~g} / \mathrm{cc}$.

4. Unconfined Compressive strength of BCS is $44.44 \mathrm{kN} / \mathrm{m}^{2}$ and the maximum strength obtained is for $15 \%$ RHA and the value is $68.677 \%$.

5. The CBR percent for BCS alone is $2.2 \%$ for $2.5 \mathrm{~mm}$ penetration and the maximum percentage obtained is $2.9 \%$ for the addition of $10 \%$ of RHA.

\subsection{Effect of CR on BCS}

The optimum proportion of Crumb Rubber blended with Black Cotton Soil which yields better results when compared to the other proportions of CR is enumerated below:

1. LL initially for BCS is $69 \%$ and on addition of CR LL reduces up to an increment of $15 \%$ and the value was found to be $35 \%$ and on further increment the LL increases.

2. PL initially for BCS is $37.5 \%$ and on addition of CR PL decreases up to an increment of $15 \%$ and was found to be $32.65 \%$ and on further increment the PL increases.

3. OMC and MDD for BCS alone is $24 \%$ and $1.7 \mathrm{~g} / \mathrm{cc}$ respectively and on addition of CR the OMC value decreases upto an increment of $10 \% \mathrm{CR}$ and the value is 
$14 \%$, similarly the MDD value increases upto $10 \%$ increment of RHA and the value is $1.72 \mathrm{~g} / \mathrm{cc}$.

4. Unconfined Compressive strength of BCS is $44.44 \mathrm{kN} / \mathrm{m}^{2}$ and the maximum strength obtained is for $10 \%$ CR and the value is $53.6 \%$.

5. The CBR percent for BCS alone is $2.2 \%$ for $2.5 \mathrm{~mm}$ penetration and the maximum percentage obtained is $3.27 \%$ for the addition of $10 \%$ of CR.

\subsection{Effect of combination of RHA and CR in equal proportion on BCS}

The optimum proportion of combination of Rice Husk ash and Crumb Rubber blended with Black Cotton Soil which yields better results when compared to the other proportions of $\mathrm{RHA}+\mathrm{CR}$ is enumerated below:

1. LL initially for BCS is $69 \%$ and on addition of RHA+CR, LL reduces up to an increment of $20 \%$ and the value was found to be $34 \%$ and on further increment the LL increases.

2. PL initially for BCS is $37.5 \%$ and on addition of RHA+CR, PL decreases up to an increment of $15 \%$ and was found to be $16.7 \%$ and on further increment the PL increases.

3. OMC and MDD for BCS alone is $24 \%$ and $1.7 \mathrm{~g} / \mathrm{cc}$ respectively and on addition of CR the OMC value decreases upto an increment of $15 \%$ RHA+CR and the value is $18 \%$, similarly the MDD value increases upto $15 \%$ increment of $\mathrm{RHA}+\mathrm{CR}$ and the value is $1.73 \mathrm{~g} / \mathrm{cc}$.

4. Unconfined Compressive strength of BCS is $44.44 \mathrm{kN} / \mathrm{m}^{2}$ and the maximum strength obtained is for $15 \%$ RHA+CR and the value is $85.34 \%$.

5. The CBR percent for BCS alone is $2.2 \%$ for $2.5 \mathrm{~mm}$ penetration and the maximum percentage obtained is $2.915 \%$ for the addition of $15 \%$ of RHA+CR.

\section{CONCLUSIONS}

1. It is observed that the Liquid Limit, Plastic Limit, Plasticity Index, Flow Index is found to be decreasing on addition of optimum proportion of 15\% RHA+CR blended with Black Cotton soil when compared with BCS alone which reduces the potential towards swelling and shrinkage and also the loss in shear strength of soil is minimized.

2. It is observed that the Optimum Moisture Content of Black Cotton soil is found to be decreasing and there is a consequent increase in Maximum Dry Density for the addition of optimum proportion of $15 \%$ RHA+CR when compared with BCS this reduces the susceptibility of soil to settlement.

3. It is observed that the Unconfined Compressive strength of Black Cotton soil is found to be increasing for the addition of optimum proportion of $15 \%$ of RHA+CR when compared with BCS which increases the stiffness of the Black Cotton Soil.

4. It is observed that the CBR percentage of Black Cotton soil is found to increase for the optimum proportion of optimum proportion of $15 \%$ RHA+CR when compared with increases the bearing capacity of soil.

5. The utilization of $15 \%$ of combination of Rice Husk Ash and Crumb Rubber is considered as the optimum proportion and it marks quite an improvement in the geotechnical properties of Black Cotton Soil which is considered as a weak soil and thus, BCS is stabilized. These soil stabilizers strengthen the BCS and the swell-shrink intensity is reduced.

6. The investigations demonstrates that RHA and CR can be made used in treating expansive soil and to a certain extent the environmental problem of waste tyre and agricultural waste disposal is being solved.

\section{SCOPE FOR FURTHER STUDY}

1. The determination of Shrinkage limit, Triaxial Compression test, Direct Shear test, Permeability test for the varying proportions of soil stabilizers are to be carried out.

2. Field determination of the geotechnical properties of Black Cotton Soil can be implemented and studied. 
3. CBR percent characteristics for the varying curing period are to be carried out.

4. Extensive research can be carried out by blending the Black Cotton soil with other materials like Flyash, Burnt Brick Dust, Crushed Glass, Cement Dust, Bitumen etc, in their varying proportions which can partially solve the disposal problem and reduce its environmental impact.

\section{REFERENCES}

[1] Vishal Gutke, Pranita Bhandari, Vikash Agarwal (2018), “Stabilization of soil by using Rice Husk Ash” IJES

[2] Jai Prakash,Kusum Kumari, Vijay Kumar(2017), "Stabilization of soil using Rice Husk Ash”, IJIRSET Vol.6, Issue 7

[3] V.S.Ghutke, Dr.S.A.Dhale, P.S.Bhandari (2017), "Stabilization of black cotton soil by using Rice husk ash, fly ash and coconut fiber" IJEEBS Vol.4 Issue 2

[4] Leonard Behak(2017), "Soil stabilization with Rice husk ash", INTECH, Research gate

[5] Rathan RajR, Bhanupriya, Dharani (2016), "Stabilization of soil using Rice husk ash", IJCER Vol. 06 Issue 02

[6] Vishnu T.C, Raseem Rasheed, Rameesha.K(2016), "Soil stabilization using Rice husk ash, Lime and Jute", SSRG - IJCE Vol.3 Issue 2

[7] Dilip Shrivasthava, A.K.Singhai, R.K.Yadav(2014), "Effect of Lime and Rice Husk Ash on engineering properties of Black cotton soil”,IJERST Vol.3

[8] Jitendra Singh Yadav (2017), “Influence of Crumb rubber on the geotechnical properties of clayey soil”, Springer Science

[9] L.Kokila, G.Bhavithra, V.Haripriya(2017), "Experimental Investigation on soil stabilization using Rubber Crumbs on expansive soils”, WJRR Vol.4 Issue 4

[11] P.T.Ravichandran,K.Divya

Krishnan(2016), "Effect of addition of waste tyre crumb rubber on weak soil stabilization” IJST Vol.9 Issue 5

[12] B.SriVasavi, Dr.D.S.V.Prasad(2016), "Stabilization of Expansive soil using Crumb rubber powder and Cement”, IJIRT Vol.2 Issue 08
[13] YadavJ.S, S.K.Tiwari(2016), "Effect of inclusion of Crumb rubber on the unconfined compressive strength and wetdry durability of cement stabilized clayey soil”, ISSN 2353-0057 J.Build.Mater. Struct.

[14] Ghagte Sandeep Hambirao, Dr.P.G.Rakaraddi(2014), "Soil Stabilization using Waste shredded Rubber Tyre chips", IOSR-JMCE Vol.11 Issue 1

[15] IS:2720(Part 4)- 1985 Methods of test for soils: Grain Size Analysis

[16] IS:2720 (Part 2)-1973 Methods of test for soils: Determination of water content

[17] IS:2720 (Part 03-01) - 1980 Methods of test for soils: Determination of specific gravity of fine-grained soil

[18] IS:2720 (Part 05)-1985 Methods of test for soils: Determination of liquid and plastic limit

[19] IS:2720 (Part 06)-1972 Methods of test for soils: Determination of shrinkage factors

[20] IS:2720 (Part 07)-1980 Methods of test for soils: Determination of water content-dry density relation using light compaction

[21] IS:2720 (Part 10)-1991 Methods of test for soils: Determination of unconfined compressive strength

[22] IS: 2720 (Part 16)-1987 Methods of test for soils: Laboratory determination of CBR 